\title{
Soybean (Glycine max L.) isoflavones: Chemical composition and its chemometrics-assisted extraction and authentication
}

\author{
Florentinus Dika Octa Riswanto ${ }^{1,2}$, Abdul Rohman $^{2}$, Suwidjiyo Pramono ${ }^{3}$, Sudibyo Martono $^{2 *}$ \\ ${ }^{1}$ Department of Pharmacy, Faculty of Pharmacy, Universitas Sanata Dharma, Campus III Paingan, Maguwoharjo, Depok, Sleman, Yogyakarta 55282, Indonesia \\ ${ }^{2}$ Department of Pharmaceutical Chemistry, Faculty of Pharmacy, Universitas Gadjah Mada, Yogyakarta 55281, Indonesia \\ ${ }^{3}$ Department of Pharmaceutical Biology, Faculty of Pharmacy, Universitas Gadjah Mada, Yogyakarta 55281, Indonesia
}

\section{ARTICLE INFO \\ Received on: $31 / 05 / 2020$ \\ Accepted on: 14/11/2020 \\ Available online: 05/01/2021}

\section{Key words:}

Authentication,

chemometrics, extraction,

isoflavones, soybean.

\begin{abstract}
Soybeans (Glycine max L.), a functional food widely consumed in Asia, has been reported as the main source of isoflavones. Phytoestrogen properties of soy isoflavones showed their activity as ligands for estrogen receptors and exhibited the estrogenic potency as reported in the previous in vitro and in vivo studies. Soy foods became most popular due to their benefits to human health and body function. The utilization of chemometrics in soybean isoflavones extraction and authentication was reported along with the increasing trends of computational analytical chemistry. A review on isoflavones contents in soybean, as well as its chemometrics-assisted extraction and authentication, is presented. This review aimed to report isoflavones contents in soybean, optimization designs for isoflavones extraction, and chemometrics algorithms for authentication purposes of soy-related products.
\end{abstract}

\section{INTRODUCTION}

Isoflavonoids, a plant's secondary metabolites class, are flavonoid compounds produced by the Fabaceae family (Danciu et al., 2017). Several plants were reported to be sources of isoflavones, such as Pueraria lobata (Kaufman et al., 1997), Medicago sativa (Soto-Zarazúa et al., 2016), Vigna radiata (Zaheer and Humayoun Akhtar, 2017), Trifolium pratense (Pakalapati et al., 2009), and Glycine max (Liu et al., 2014; Messina, 1999). Soybeans (Glycine $\max \mathrm{L}$.) are reported to be one of the main sources of dietary isoflavones and are well known as a healthy food with a high quality of protein, fatty acids, and other healthy components (Wang et al., 2011). Soy products have been widely consumed in several Asian countries and are served as various kinds of food, such as tempeh, tofu, soymilk, miso, soy nuts, and many more (Messina et al., 2006).

\section{"Corresponding Author}

Sudibyo Martono, Department of Pharmaceutical Chemistry, Faculty of Pharmacy, Universitas Gadjah Mada, Yogyakarta, Indonesia. E-mail: sudibyo_martono@ugm.ac.id
In two last decades, soy products were not only consumed as one of the functional foods but also were reported to provide several benefits on cardiovascular health, bone health, kidney function, cognitive function, mental health, skin health, reproduction function, thyroid function, and anticancer (Messina, 2016). The research interest on anticancer activities of soy isoflavones has increased in recent years due to their beneficial effects on the prostate cancer (Dong, 2011; Sivoňová et al., 2018; Sugiyama et al., 2013; Zhang et al., 2016), breast cancer (Boucher et al., 2013; Kang et al., 2010; Yuliani et al., 2016; Ziaei and Halaby, 2017), ovarian cancer (Lee et al., 2012; Zhuang et al., 2010), and colorectal cancer (Shafiee et al., 2016; Yu et al., 2016). Previous studies was reported that the biological activities of soy foods were linked to the presence of the soy isoflavones (Lissin and Cooke, 2000; Valsecchi et al., 2011). The major soy isoflavones consist of isoflavone aglycones, namely, genistein, daidzein, and glycitein, and their glucosides (i.e., genistin, daidzin, and glycitin) (Křížová et al., 2019; Yatsu et al., 2016). It was also reported that the content percentage of genistein, daidzein, and glycitein werewas about $50 \%, 40 \%$, and $10 \%$ from total isoflavone profiles, respectively (Hassan, 2013). However, the abundance of isoflavones in several soy products was varied due to their 
production or processing technique, as well as their extraction process (Anderson and Wolf, 1995; Erdman et al., 2004; Yuliani et al., 2019).

The conventional extraction method using one variable at a time approach can be developed in natural product extraction. Nevertheless, this approach was time-consuming and expensive for optimization (Banik and Pandey, 2008). It was important to develop an effective and more economical method for selecting extraction parameters, such as extraction duration, composition of solvent, pH, temperature, and solid to liquid (Anuar et al., 2013; Borges et al., 2011; Wijngaard and Brunton, 2010). Chemometrics, a combination method of mathematics and statistics to solve all types of chemical problems, can be applied in the method development (Miller and Miller, 2010). Chemometrics techniques were applicable in the optimization stage since the experimental design was stated as one of the specific areas in the chemometrics scope (Brereton, 2018). The advantage of applying experimental design in the optimization stage is the possibility to observe the interaction between different variables (Myers et al., 2016). The design of the experiment can be carried out in natural product science, especially in the optimization process for extraction method with the application of response surface methodology (RSM) techniques, namely, full factorial design (FFD), Box--
Behnken design (BBD), central composite design (CCD), and Doehlert design (Riswanto et al., 2019).

The employment of chemometrics in soy research was not only for the optimization process but also for the authentication process. Food authentication is described as the verification process to ensure that food or sample material complies with the label description, such as the origin, method, or processing technology used for the production (Danezis et al., 2016). The trend of authentication research has been increasing since it was reported that the chemometrics of pattern recognition and multivariate analysis play an important role in plants identification, fingerprinting profiling, species discrimination, and metabolite analysis (Caligiani et al., 2010; Gerbig et al., 2017; Pompeu et al., 2018; Wehrens, 2011). Principal component analysis (PCA) is a commonly used algorithm for dimensionality reduction since it provided a variance profile for each group in a set of multivariate data (Gromski et al., 2015). Other chemometrics algorithms such as partial least squarediscriminant analysis (PLS-DA) and cluster analysis (CA) were also applied in natural product analysis (Hong et al., 2011; Shen et al., 2018). Aiming to present integrative information of soybean isoflavones, this review discusses the chemical composition of isoflavones contained in soybeans, as well as chemometrics techniques for isoflavones extraction and authentication.

Table 1. Isoflavone structures and their glucosides.

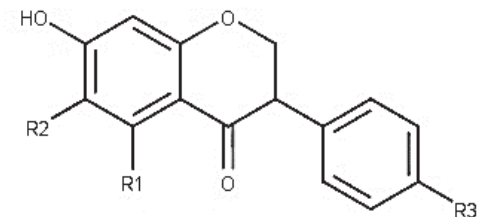

(a)

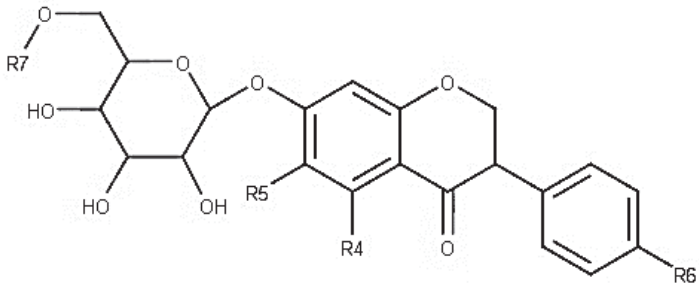

(b)

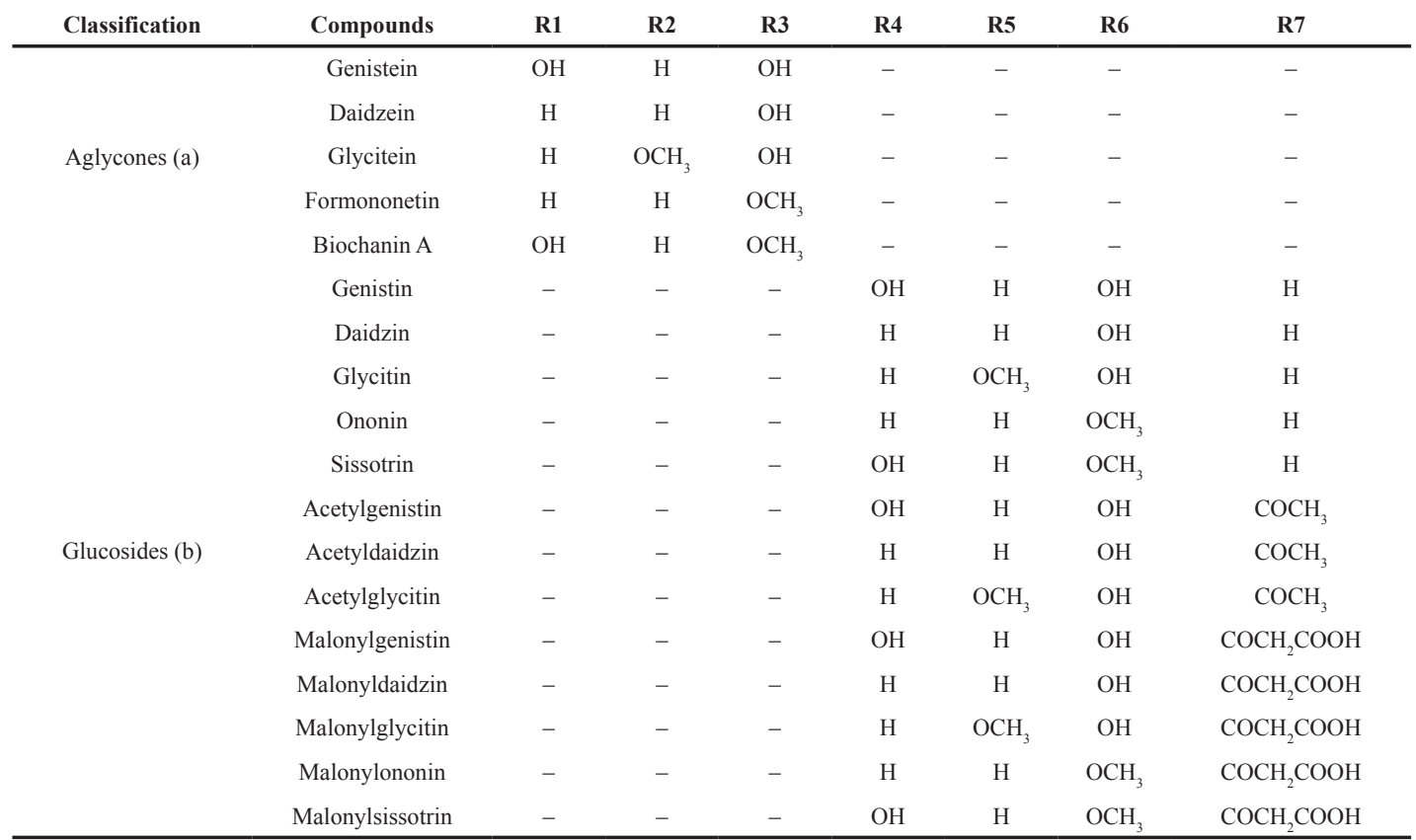

Adapted from (Daems et al., 2016; Kř́ǐzová et al., 2019). 


\section{METHODS}

This review article was accomplished by identifying, investigating, and assembling numerous review articles, original articles, and related books from reputable databases, such as Web of Science, PubMed, and Scopus. Supporting references from books, journal articles, and scientific reports were accessed utilizing facilities provided by Universitas Gadjah Mada, Indonesia. The literature investigation process was conducted between July and August 2020. The keywords explored during literature searching consisted of "Glycine max L.", "isoflavones", "soybean isoflavones content", "isoflavones anticancer activities", "experimental design of extraction", and "Glycine max L. authentication".

\section{CHEMICAL COMPOSITION}

Isoflavones, a very important biologically active class of compounds contained in soybean, are recognized because of their benefits to human health (Ferreira et al., 2011). Table 1 presents the structures of the isoflavones and their glucosides. Isoflavones can be categorized into aglycones and glucosides due to the presence of sugar moiety linked to hydroxyl groups (Yatsu et al., 2016). In soybeans, there are 12 main isoflavones such as free aglycones (daidzein, genistein, and glycitein), their respective glucosides (daidzin, genistin, and glycitin), acetyl glucosides (acetyldaidzin, acetylgenistin, and acetylglycitin), and malonyl glucosides (malonyldaidzin, malonylgenistin, and malonylglycitin) (Rostagno et al., 2007).

In previous studies, it was reported that the isoflavones content increased along with the occurrence of the fermentation process (Chaiyasut et al., 2010; Rostagno et al., 2007). The use of Bacillus subtilis natto (B. natto) successfully enhanced the concentration of genistein and daidzein eight times higher compared to those in the raw soybean (Hasim et al., 2015). Other researchers reported that the content of genistein, daidzein, and glycitein increased within three 3 days of fermentation with the utilization of Rhizopus oligosporus (Kuligowski et al., 2017). Hence, fermentation products of soybeans, such as tempeh, attracted much attention and became popular to be studied in the last decade (Bavia et al., 2012; Haron et al., 2009, 2011; Jeleń et al., 2013).

Soybeans isoflavones in several publications have been stated as flavonoids phytoestrogen (Hughes, 2003; Kř́žová et al., 2019). Phytoestrogen was described as natural compounds from plants characterized by their molecular structure and size, resemblingd estrogen, especially estradiol, and showed estrogenic and/or antiestrogenic activities (Kurzer and Xu, 1997). Isoflavones have been linked to estradiol since these compounds showed the similarity of the structure to estradiol as a human hormone (Kř́žzová et al., 2019). Although isoflavones and estradiol structures showed several differences, the moiety of phenol groups enabled interaction with estrogen receptors (ER) and activated this receptor accordingly (Wang et al., 2008). Figure 1 shows the similarity of structures and their phenolic/hydroxylic profiles of estradiol and three main isoflavone aglycones in soybeans.

According to previous publications on in vitro and in vivo studies, the estrogenic potency from the highest to the lowest was supposed as estradiol, genistein, glycitein, daidzein, formononetin, and biochanin A, respectively (Hughes, 2003). Soybean isoflavones, similar to other phytoestrogens, showed their

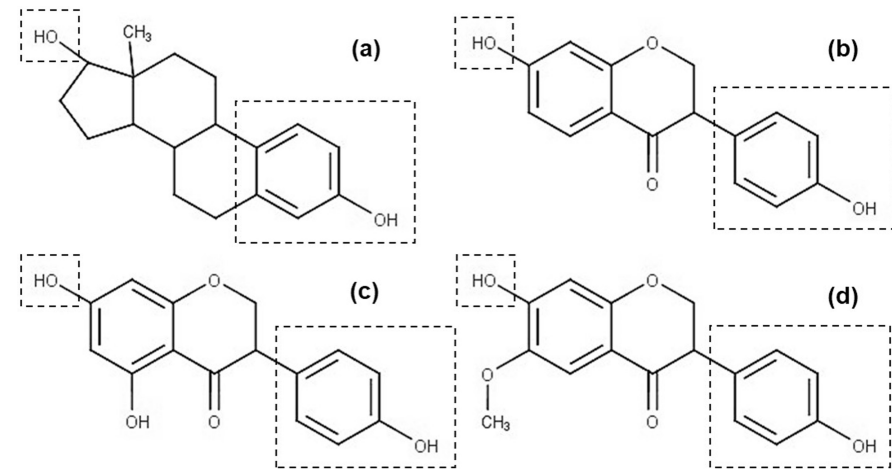

Figure 1. Structure similarities of estradiol (a) and three main isoflavone aglycones in soybeans, namely daidzein (b), genistein (c), and glycitein (d). The dotted lines indicate the phenolic and hydroxyl moieties.

activity as ligands for ER (Matsuda et al., 2001; Messina et al., 2006), a biomarker of breast cancer (Ali et al., 2011; Shiau et al., 1998). Among the soy isoflavones, genistein became the most popular studied compound since it plays an important role as a reference ligand for both estrogen receptor $\alpha(\mathrm{ER} \alpha)$ and estrogen receptor $\beta$ (Helferich et al., 2008; Istyastono et al., 2017; Morito et al., 2002). Genistein is also reported with its capability of crossing the blood-brain barrier and producing antioxidant activities against radiation of ultraviolet and chemicals (Zeng et al., 2004).

\section{CHEMOMETRICS-ASSISTED ISOFLAVONES EXTRACTION}

A modern approach to the optimization process was commonly conducted by employing a computational experimental design (Kleijnen, 2010). In natural product chemistry, experimental designs can be applied in analytical method development (Prabaningdyah et al., 2017; Riswanto et al., 2020; Siregar et al., 2017), biological product enhancement (Farombi et al., 2018; Managamuri et al., 2017; Momen et al., 2016; Srivastava et al., 2018; Talluri et al., 2019), and parameters selection for efficiency and economic consideration in biochemical processing (Ciechomska et al., 2016; Ha et al., 2018; Merib et al., 2014; Xiong et al., 2016).

The extraction process of soybean isoflavones can be carried out using several extraction techniques such as maceration, ultrasonication, filtration, agitation, and centrifugation. Extraction process optimization combined with experimental designs for isoflavones extraction can be conducted with RSM techniques, namely, FFD, simplex centroid design (SCD), CCD, and BBD. Table 2 presents the list of reported chemometrics designs and techniques in soybean isoflavone extraction studies.

FFD has been successfully applied for optimizing the process of extraction of genistein and daidzein from dried tempeh, a fermented product of soybean. Tempeh powder was macerated and extracted using a liquid-liquid extraction (LLE) technique. An optimal extraction condition was obtained with the usage of ethanol $96 \%$, the particle size of $0.6 \mathrm{~mm}$, and the extraction time of 270 minutes. Total genistein and daidzein achieved from the optimal method were $26.03 \mathrm{mg} \%$ and $19.42 \mathrm{mg} \%$, respectively (Yuliani et al., 2018). SCD and other types of RSM belong to a mixture experiment in which the variables are the mixture components and the responses are the formula of the proportions of 
Table 2. The employment of chemometrics in soybean isoflavone extraction studies.

\begin{tabular}{|c|c|c|c|}
\hline Samples/Sources & Extraction Techniques & Designs & References \\
\hline Tempeh & Maceration, LLE & FFD & (Yuliani et al., 2018) \\
\hline Soybeans (BRS 257 cultivar) & $\begin{array}{l}\text { Ultrasonication, centrifugation, } \\
\text { filtration }\end{array}$ & SCD & (Yoshiara et al., 2012) \\
\hline Soybean seeds (DT2010 cultivar) & Maceration & $\mathrm{CCD}$ & (Le et al., 2019) \\
\hline Soybeans (BRS 257 cultivar) & Agitation, centrifugation & $\mathrm{CCD}$ & (Yoshiara et al., 2018) \\
\hline Soybeans (JS 335 cultivar) & $\begin{array}{l}\text { Leaching, membrane process, and } \\
\text { LLE- }\end{array}$ & $\mathrm{CCD}$ & (Lakshmi et al., 2013) \\
\hline Soy flour & Agitation, fractionation & BBD & (Abdella et al., 2018) \\
\hline Black soybean variety VL Bhatt & CSE, MAE, EAE & BBD & (Kumar et al., 2019) \\
\hline Chinese soybean cheese & UAE & $\mathrm{BBD}$ & (Jianming et al., 2013) \\
\hline $\begin{array}{l}\text { Soybean from the Guangdong } \\
\text { Inspection and Quarantine } \\
\text { Technology Center }\end{array}$ & QuEChERS method & BBD & (Ding et al., 2016) \\
\hline
\end{tabular}

each ingredient (Myers et al., 2016). Yoshiara et al. (2012) carried out soy isoflavone extraction and optimized the solvent polarity by varying the composition of four solvents, namely, water, acetone, ethanol, and acetonitrile. After conducting extraction techniques, including ultrasonication, centrifugation, and filtration, the content of different soy isoflavones was stated as a response function and determined using a validated high-performance liquid chromatography (HPLC) method. It was found that malonylglycosidic and total forms can be optimally extracted using water : acetone : ethanol (2:1:1, by volume); glycosidic isoflavones were best extracted using water : acetone : acetonitrile $(2: 1: 1$, by volume), and the less polar aglycone forms were extracted with water : acetone (1: 1, by volume) (Yoshiara et al., 2012).

CCD, a type of RSM technique introduced by Box and Wilson (1951), was composed of three parts, including full factorial or fractional factorial design, star points, and center point (Box and Wilson, 1951). This design was successfully generated and applied for optimizing isoflavones extraction of soybean of DT2010 (Le et al., 2019), BRS 257 (Yoshiara et al., 2018) and JS 335 cultivar (Lakshmi et al., 2013). Several optimization parameters, namely, solvent concentration, extraction time, reaction temperature, solvent-material ratio, and $\mathrm{pH}$, can be defined as experimental factors to achieve optimized extraction conditions.

BBD became the most popular RSM technique for optimization since it was more efficient and economically effective than the other three-level experimental designs, mainly for a large number of variables (Bezerra et al., 2008; Box and Behnken, 1960). This design has been widely used since there are no factorial or extreme points of experiments (Riswanto et al., 2019). BBD can be applied to observe not only conventional extraction techniques such as agitation and fractionation (Abdella et al., 2018) but also more sophisticated techniques for modern extraction studies. BBD has been applied in a comparison study of conventional solvent extraction (CSE), microwave-assisted extraction (MAE), and enzyme-assisted extraction (EAE) for extracting total phenolics and anthocyanins from the sample of black soybean variety VL Bhatt (Kumar et al., 2019). Another modern extraction technique using ultrasound-assisted extraction (UAE) has been utilized by the $\mathrm{BBD}$ technique for determining total isoflavones content in cheese from Chinese soybean (Jianming et al., 2013). The UAE technique proved to increase the extraction efficiency compared to the mix-stirring extraction for extracting isoflavone derivatives, such as daidzin, glycitin, genistein, and malonyl genistin from freeze-dried ground soybeans (Rostagno et al., 2003). A quick, easy, cheap, effective, rugged, and safe (QuEChERS) method coupled with high-resolution liquid chromatography quadrupole times of flight mass spectrometry was developed to extract, identify, and quantify daidzein, glycitein, genistein, daidzin, glycitin, and genistin in soybeans from the Guangdong Inspection and Quarantine Technology Center. The extraction conditions of soybean isoflavones by using the QuEChERS method were achieved as follows: $\mathrm{MgSO} 4$ and $\mathrm{NaCl}$ of 1.0 and $0.25 \mathrm{~g}$, respectively; acetonitrile and water ratio of $70: 30(\mathrm{v} / \mathrm{v})$; and ultrasonic duration of 20 minutes (Ding et al., 2016).

\section{CHEMOMETRICS-ASSISTED ISOFLAVONES AUTHENTICATION}

In natural product and food analysis, the authentication process was more important and was addressed to ensure the quality and safety of the samples (Irnawati et al., 2020, 2021; Putri et al., 2021; Rohman et al., 2011; Suhandy and Yulia, 2019). By combining statistical and mathematical techniques and chemistry data, chemometrics can be performed to observe data output from analytical instruments such as high-HPLC, liquid chromatography-mass spectrometry (LC-MS), infrared spectroscopy, and quadrupole time of flight mass spectrometer (QTOF-MS). Chemometrics algorithms including PCA, PLS-DA, $\mathrm{CA}$, and partial least squares regression (PLSR) were employed for specific authentication purposes. Table 3 presents the listed reports of chemometrics algorithms and instrumentation used in soybean isoflavone authentication studies.

PCA algorithm has been widely used in almost all scientific disciplines and probably the most popular chemometrics technique in authentication analysis (Rohman and Putri, 2019). As a chemometrics technique, PCA was chosen to performcarry 
Table 3. The employment of chemometrics in soybean isoflavone authentication studies.

\begin{tabular}{|c|c|c|c|c|}
\hline Samples/sources & Instruments & Chemometrics & Aim of the study & References \\
\hline $\begin{array}{l}\text { Soybean seeds BRS } 25 \\
\text { cultivar }\end{array}$ & HPLC & PCA & $\begin{array}{l}\text { Observing the relationship between the } \\
\text { distributions of isoflavones to the various } \\
\text { roasting treatments used to create the flour }\end{array}$ & Giaretta et al., 2015 \\
\hline Soybeans & HPLC; QTOF-MS & PCA & $\begin{array}{l}\text { Identifying the multivariate trends of } \\
\text { isoflavone aglycones in soybeans treated } \\
\text { by drying and storage process }\end{array}$ & Ferreira et al., 2019 \\
\hline Soybeans & HPLC & PCA & $\begin{array}{l}\text { Investigating the increase of isoflavones in } \\
\text { the aglycone form }\end{array}$ & Miladinović et al., 2019 \\
\hline 1168 soybean accessions & HPLC & PCA & $\begin{array}{l}\text { Profiling the seed isoflavone composition } \\
\text { of } 1168 \text { soybean accessions }\end{array}$ & Azam et al., 2020 \\
\hline $\begin{array}{l}\text { Wild soybeans, cultivated } \\
\text { soybeans, and bean } \\
\text { products }\end{array}$ & HPLC; LC-MS & PCA; $\mathrm{CA}$ & $\begin{array}{l}\text { Developing an analytical method to } \\
\text { evaluate the quality of wild soybean, } \\
\text { cultivated soybean, and bean products }\end{array}$ & Hong et al., 2011 \\
\hline Soybean mutants & Raman spectroscopic & PCA; $\mathrm{CA}$ & $\begin{array}{l}\text { Demonstrating a reliable fast determination } \\
\text { and discrimination between the mutants } \\
\text { and control groups }\end{array}$ & Ogruc Ildiz et al., 2020 \\
\hline 44 varieties of the soybean & HPLC & PLS-DA; CA & $\begin{array}{l}\text { Metabolite profiling for assessing the } \\
\text { quality of food soybeans from China, } \\
\text { Japan, and Korea }\end{array}$ & Kim et al., 2014 \\
\hline $\begin{array}{l}\text { Chinese and Korean } \\
\text { soybeans }\end{array}$ & FTIR & PLS-DA; PLSR; CA & $\begin{array}{l}\text { Combining FTIR with chemometrics } \\
\text { techniques for discriminating Chinese and } \\
\text { Korean soybeans }\end{array}$ & Lee et al., 2018 \\
\hline
\end{tabular}

PCA = principal component analysis; $\mathrm{CA}$ = cluster analysis; PLS-DA = partial least squares discriminant analysis; PLSR = partial least squares regression.

out the dimensionality reduction of the data when a correlation was present (Miller and Miller, 2010). The advantage of PCA is the possibility to generate principal components for further analysis or data visualization (Brereton, 2007). In soybean isoflavone analysis, PCA was used to observe the relationship between the distributions of isoflavones of soybean seeds BRS 25 cultivar (Giaretta et al., 2015), identify the multivariate trends of isoflavone aglycones (Ferreira et al., 2019), and investigate the increased content of isoflavone aglycones (Miladinović et al., 2019) and isoflavones profiling (Azam et al., 2020). HPLC was the commonly used analytical instrumentation since it was possible to result in a separation profile of the presence analytes in the matrix or mixture samples (Snyder et al., 2010).

PCA can be coupled with other chemometrics algorithms, such as CA, a method for objects grouping into classes, so that similar objects are in the same class (Miller and Miller, 2010). This chemometrics technique combination resulted in good contribution to evaluate the quality of wild soybean, cultivated soybean, and bean products (Hong et al., 2011). Another study by Ogruc Ildiz et al. (2020) was conducted by using Raman spectroscopy coupled with PCA and CA. The determination and discrimination were between the mutants and control group of soybeans (Ogruc Ildiz et al., 2020).

PLS-DA was recognized as the most well-known classification procedure in chemometrics (Brereton and Lloyd, 2014). This chemometrics approach has been extensively employed in the field of metabolomics studies (Gomez et al., 2018; Gromski et al., 2015). Metabolite profiling using HPLC method combined with PLS-DA and CA for assessing the quality of food soybeans from China, Japan, and Korea has been successfully conducted (Kim et al., 2014). The studyies by Lee et al. (2018) reported the employment of Fourier transform infrared (FTIR) spectroscopy in combination with PLS-DA and CA to discriminate between
Chinese and Korean soybeans. In this study, the PLSR model was generated to determine the origin of soybeans using the appropriate wavenumber selection (Lee et al., 2018).

It is interesting to explore more about the chemical compositions in soybeans and soybean products by carrying out research employed with chemometrics techniques. Our future research will be focused on the isoflavone aglycones analysis of soybean products. Chemometrics techniques will be applied to determination genistein, daidzein, and glycitein by generating predictive models for each compound compared to a validated chromatographic method, such as HPLC.

\section{CONCLUSION}

Soybean is a valuable and powerful functional food due to its benefits to human health. Phytoestrogen activity of soybean foods was linked to estradiol since these isoflavone compounds showed a structural similarity. Isoflavones content in soybean also exhibit several biological activities on cardiovascular, bone, mental, and skin health, as well as improve cognitive, kidney, reproduction, and thyroid function.

Chemometrics of the experimental design can be applied in the soybean isoflavones extraction for selecting extraction conditions including solvent concentration, extraction time, reaction temperature, solvent-material ratio, and $\mathrm{pH}$. RSM techniques of FFD, SCD, CCD, and BBD have been reported as a computational optimization approach in numerous papers. The authentication process of soybean isoflavones was carried out for assuring the quality and safety of soy foods. Analytical data collected from analytical instrumentations, such as HPLC, QTOFMS, LC-MS, and infrared spectrophotometer, can be processed using appropriate chemometrics algorithms of PCA, PLS-DA, $\mathrm{CA}$, and/or PLSR to provide useful information in the fields of analytical chemistry. 


\section{ACKNOWLEDGMENTS}

The authors acknowledge the Faculty of Pharmacy, Universitas Gadjah Mada, Indonesia, for providing the facilities. This review article was a part of a research financially supported by Thesis Recognition Program 2020 (Rekognisi Tugas Akhir 2020), Directorate of Research Universitas Gadjah Mada (no. 2488/UN1.P.III/DIT-LIT/PT/2020), awarded to Professor Dr. apt. Sudibyo Martono, MS.

\section{AUTHORS' CONTRIBUTIONS}

Florentinus Dika Octa Riswanto carried out the literature search and drafted the manuscript. Abdul Rohman reviewed the initial draft of the manuscript and supervised the content in the field of chemometrics for both extraction and authentication. Suwidjiyo Pramono reviewed the initial draft of the manuscript and supervised a substantial part in the field of natural materials research and extraction techniques. Sudibyo Martono provided the conceptualization of the article and supervised the content in the field of pharmaceutical chemistry and instrumental analysis.

\section{CONFLICT OF INTEREST}

The authors declare that they have no conflicts of interest.

\section{FUNDING}

None.

\section{ETHICAL APPROVAL}

This study does not involve the use of animals or human subjects.

\section{REFERENCES}

Abdella A, El baz AF, Mahrous EE, El Maksoud AAA, Ibrahim IA, Abdel-Monem AR, Yang ST. Response surface methodology for optimization of genistein content in soy flour and its effect on the antioxidant activity. Iran J Pharm Res, 2018; 17(3):1026-35.

Ali S, Buluwela L, Coombes RC. Antiestrogens and their therapeutic applications in breast cancer and other diseases. Annu Rev Med, $2011 ; 62: 217-32$

Anderson RL, Wolf WJ. Compositional changes in trypsin inhibitors, phytic acid, saponins and isoflavones related to soybean processing. J Nutr, 1995; 125:581-8.

Anuar N, Mohd Adnan AF, Saat N, Aziz N, Mat Taha R. Optimization of extraction parameters by using response surface methodology, purification, and identification of anthocyanin pigments in Melastoma malabathricum fruit. Sci World J, 2013; 2013:1-10.

Azam M, Zhang S, Abdelghany AM, Shaibu AS, Feng Y, Li Y, Tian Y, Hong H, Li B, Sun J. Seed isoflavone profiling of 1168 soybean accessions from major growing ecoregions in China. Food Res Int, 2020; 130:108957.

Banik RM, Pandey DK. Optimizing conditions for oleanolic acid extraction from Lantana camara roots using response surface methodology. Ind Crops Prod, 2008; 27:241-8.

Bavia ACF, Silva CE da, Ferreira MP, Leite RS, Mandarino JMG, Carrão-Panizzi MC. Chemical composition of tempeh from soybean cultivars specially developed for human consumption. Food Sci Technol, 2012; 32(3):613-20.

Bezerra MA, Santelli RE, Oliveira EP, Villar LS, Escaleira LA. Response surface methodology (RSM) as a tool for optimization in analytical chemistry. Talanta, 2008; 76(5):965-77.

Borges GDSC, Vieira FGK, Copetti C, Gonzaga LV, Fett R. Optimization of the extraction of flavanols and anthocyanins from the fruit pulp of Euterpe edulis using the response surface methodology. Food Res Int, 2011; 44(3):708-15.

Boucher BA, Cotterchio M, Anderson LN, Kreiger N, Kirsh VA, Thompson LU. Use of isoflavone supplements is associated with reduced postmenopausal breast cancer risk. Int J Cancer, 2013; 132(6):1439-50.

Box GEP, Behnken DW. Some new three level designs for the study of quantitative variables some new three level designs for the study of quantitative variables. Technometrics, 1960; 2(4):455-75.

Box GEP, Wilson KB. On the experimental attainment of optimum conditions. J R Stat Soc Ser B, 1951; 13(1):1-45.

Brereton RG. Applied chemometrics for scientists. John Wiley \& Sons Ltd, Chichester, UK, 2007.

Brereton RG. Chemometrics: data driven extraction for science. 2nd edition, John Wiley \& Sons Ltd, Croydon, UK, 2018.

Brereton RG, Lloyd GR. Partial least squares discriminant analysis: taking the magic away. J Chemom, 2014; 28:213-25.

Caligiani A, Palla G, Maietti A, Cirlini M, Brandolini V. 1H NMR fingerprinting of soybean extracts, with emphasis on identification and quantification of isoflavones. Nutrients, 2010; 2(3):280-9.

Chaiyasut C, Kumar T, Tipduangta P, Rungseevijitprapa W. Isoflavone content and antioxidant activity of Thai fermented soybean and its capsule formulation. African J Biotechnol, 2010; 9(26):4120-6.

Ciechomska M, Woźniakiewicz M, Nowak J, Świadek K, Bazylewicz B, Kościelniak P. Development of a microwave-assisted extraction of atropine and scopolamine from Solanaceae family plants followed by a QuEChERS cleanup procedure. J Liq Chromatogr Relat Technol, 2016; 39(11):538-48.

Daems F, Romnee JM, Heuskin S, Froidmont É, Lognay G. Analytical methods used to quantify isoflavones in cow's milk: a review. Dairy Sci Technol, 2016; 96(3):261-83.

Danciu C, Oana S, Antal DS, Ardelean F, Chiş AR, Şoica C, Andrica F, Dehelean C, Brigitha V. New insights regarding the potential health benefits of isoflavones. In: Justino GC (ed.). Flavonoids - from biosynth to Hum Heal. Intech Open, Zagreb, Croatia, 2017.

Danezis GP, Tsagkaris AS, Camin F, Brusic V, Georgiou CA. Food authentication: techniques, trends \& emerging approaches. Trends Analyt Chem, 2016; 85:123-32.

Ding B, Wang Z, Yi R, Zhang S, Li X, She Z, Chen W. A modified QuEChERS method coupled with high resolution LC-Q-TOFmass spectrometry for the extraction, identification and quantification of isoflavones in soybeans. Anal Methods, 2016; 8(10):2259-66.

Dong X. Anticancer effects of daidzein, genistein and soy extracts on human prostate cancer cells [Internet]. University of Delaware, Newark, DE, 2011.

Erdman JW, Badger TM, Lampe JW, Setchell KDR, Messina M. Not all soy products are created equal: caution needed in interpretation of research results. J Nutr, 2004; 134:1229-33.

Farombi AG, Amuda OS, Alade AO, Okoya AA, Adebisi SA. Central composite design for optimization of preparation conditions and characterization of hydroxyapatite produced from catfish bones. Beni-Suef Univ J Basic Appl Sci, 2018; 7(4):474-80.

Ferreira CD, Ziegler V, Schwanz Goebel JT, Hoffmann JF, Carvalho IR, Chaves FC, De Oliveira M. Changes in phenolic acid and isoflavone contents during soybean drying and storage. J Agric Food Chem, 2019; 67(4):1146-55.

Ferreira MP, de Oliveira MCN, Mandarino JMG, da Silva JB, Ida EI, Carrão-Panizzi MC. Changes in the isoflavone profile and in the chemical composition of tempeh during processing and refrigeration. Pesqui Agropecu Bras, 2011; 46(11):1555-61.

Gerbig S, Neese S, Penner A, Spengler B, Schulz S. Real-time food authentication using a miniature mass spectrometer. Anal Chem, 2017; 89(20):10717-25.

Giaretta D, de Lima VA, Schmidt CAP, Carpes ST Chromatographic characterization of isoflavones in soy flour variety BRS 257, and recognition of their patterns by chemometrics. Food Sci Technol, 2015; 64(2):1209-16

Gomez JD, Vital CE, Oliveira MGA, Ramos HJO. Broad range flavonoid profiling by LC/MS of soybean genotypes contrasting for resistance to Anticarsia gemmatalis (Lepidoptera: Noctuidae). PLoS One, 2018; 13(10):1-24.

Gromski PS, Muhamadali H, Ellis DI, Xu Y, Correa E, Turner ML, Goodacre R. A tutorial review: metabolomics and partial least squaresdiscriminant analysis - a marriage of convenience or a shotgun wedding Anal Chim Acta, 2015; 879:10-23. 
Ha WR, Park JH, Kim JH. Optimization for decocting later of menthae herba in eungyo-san, a herbal formula, using response surface methodology with gas chromatography/mass spectrometry. Pharmacogn Mag, 2018; 14(53):17-21.

Haron H, Ismail A, Azlan A, Shahar S, Peng LS. Daidzein and genestein contents in tempeh and selected soy products. Food Chem, 2009; 115(4):1350-6.

Haron H, Ismail A, Shahar S, Azlan A, Peng LS. Apparent bioavailability of isoflavones in urinary excretions of postmenopausal Malay women consuming tempeh compared with milk. Int J Food Sci Nutr, 2011; 62(6):642-50.

Hasim, Astuti P, Falah S, Faridah DN. Bacillus subtilis natto fermentation to improve aglycone isoflavones content of black soybean varieties detam 2. Int Food Res J, 2015; 22(6):2558-64.

Hassan SM. Soybean, nutrition and health. In El-Shemy HA (ed.). Soybean - Bio-active Compd, IntechOpen Limited, London, UK, pp 453-73, 2013.

Helferich WG, Andrade JE, Hoagland MS. Phytoestrogens and breast cancer: a complex story. Inflammopharmacology, 2008; 16(5):21926.

Hong JL, Qin XY, Shu P, Wang Q, Zhou ZF, Wang GK, Lin B Bin, Wang Q, Qin MJ. Comparative study of isoflavones in wild and cultivated soybeans as well as bean products by high-performance liquid chromatography coupled with mass spectrometry and chemometric techniques. Eur Food Res Technol, 2011; 233(5):869-80.

Hughes IA. Phytoestrogens and health [Internet]. In Hughes I, Woods HF (eds.). Committee on toxicity of chemicals in food, consumer products and the environment. The Food Standards Agency, London, UK, 2003.

Irnawati, Riswanto FDO, Riyanto S, Martono S, Rohman A. The use of software packages of $\mathrm{R}$ factoextra and FactoMineR and their application in principal component analysis for authentication of oils. Indones J Chemom Pharm Anal, 2021; 1(1):1-10.

Irnawati, Riyanto $\mathrm{S}$, Martono Su, Rohman $\mathrm{A}$. The employment of FTIR spectroscopy and chemometrics for authentication of essential oil of curcuma mangga from candle nut oil. Food Res, 2020; 4(1):42-8.

Istyastono EP, Yuniarti N, Hariono M, Yuliani SH, Riswanto FDO. Binary quantitative structure-activity relationship analysis in retrospective structure-based virtual screening campaigns targeting estrogen receptor alpha. Asian J Pharm Clin Res, 2017; 10(12):206-11.

Jelen H, Majcher M, Ginja A, Kuligowski M. Determination of compounds responsible for tempeh aroma. Food Chem, 2013; 141(1):459-65.

Jianming W, Yuan G, Ping L, Feng H, Liying L. Optimization of ultrasound-assisted extraction procedure to determine total isoflavones in Chinese soybean cheese by box-behnken design. Food Anal Methods, 2013; 6(1):221-6.

Kang X, Zhang Q, Wang S, Huang X, Jin S. Effect of soy isoflavones on breast cancer recurrence and death for patients receiving adjuvant endocrine therapy. CMAJ, 2010; 182(17):1857-62.

Kaufman PB, Duke JA, Brielmann H, Boik J, Hoyt JE. A comparative survey of leguminous plants as sources of the isoflavones, genistein and daidzein: implications for human nutrition and health. J Altern Complement Med, 1997; 3:7-12.

Kim JK, Kim EH, Park I, Yu BR, Lim JD, Lee YS, Lee JH, Kim $\mathrm{SH}$, Chung IM. Isoflavones profiling of soybean [Glycine $\max (\mathrm{L}$.) Merrill] germplasms and their correlations with metabolic pathways. Food Chem, 2014; 153:258-64

Kleijnen JPC. Design and analysis of computational experiments: overview. Exp Methods Anal Optim Algorithms. Springer Berlin Heidelberg, Berlin, Germany, pp 51-72, 2010.

Křížová L, Dadáková K, Kašparovská J, Kašparovský T. Isoflavones. Molecules, 2019; 24(1076):1-28.

Kuligowski M, Pawłowska K, Jasińska-Kuligowska I, Nowak J. Isoflavone composition, polyphenols content and antioxidative activity of soybean seeds during tempeh fermentation. CyTA-J Food, 2017; $15(1): 27-33$
Kumar M, Dahuja A, Sachdev A, Kaur C, Varghese E, Saha S, Sairam KVSS. Evaluation of enzyme and microwave-assisted conditions on extraction of anthocyanins and total phenolics from black soybean (Glycine $\max$ L.) seed coat. Int J Biol Macromol, 2019; 135:1070-81.

Kurzer MS, Xu X. Dietary phytoestrogens. Annu Rev Nutr, $1997 ; 17: 353-81$.

Lakshmi MC, Rao LJ, Ravi R, Raghavarao KSMS. Extraction and concentration of isoflavones from soybean (Glycine max). Sep Sci Technol, 2013; 48(1):166-74.

Le XT, Lan Vi VL, Toan TQ, Bach LG, Truc TT, Hai Ha PT Extraction process of polyphenols from soybean (Glycine max L.) sprouts: optimization and evaluation of antioxidant activity. Processes, 2019; 7(8):489.

Lee BJ, Zhou Y, Lee JS, Shin BK, Seo JA, Lee D, Kim YS, Choi HK. Discrimination and prediction of the origin of Chinese and Korean soybeans using Fourier transform infrared spectrometry (FT-IR) with multivariate statistical analysis. PLoS One, 2018; 13(4):1-16.

Lee JY, Kim H, Song YS. Genistein as a potential anticancer agent against ovarian cancer. J Tradit Complement Med, 2012; 2(2):96-104.

Lissin LW, Cooke JP. Phytoestrogens and cardiovascular health. J Am Coll Cardiol, 2000; 35(6):1403-10.

Liu ZM, Ho SC, Chen YM, Ho S, To K, Tomlinson B, Woo J. Whole soy, but not purified daidzein, had a favorable effect on improvement of cardiovascular risks: a 6-month randomized, double-blind, and placebocontrolled trial in equol-producing postmenopausal women. Mol Nutr Food Res. 2014;58(4):709-17.

Managamuri U, Vijayalakshmi M, Poda S, Ganduri VSRK, Rajulapati SB. Optimization of operating conditions for the production of enhanced antifungal metabolites from streptomonospora arabica VSM 25 by full factorial design. J Young Pharm, 2017; 9(3):399-409.

Matsuda $\mathrm{H}$, Shimoda $\mathrm{H}$, Morikawa $\mathrm{T}$, Yoshikawa $\mathrm{M}$. Phytoestrogens from the roots of Polygonum cuspidatum (Polygonaceae): structure-requirement of hydroxyanthraquinones for estrogenic activity. Bioorganic Med Chem Lett, 2001; 11:1839-42.

Merib J, Nardini G, Carasek E. Use of doehlert design in the optimization of extraction conditions in the determination of organochlorine pesticides in bovine milk samples by HS-SPME. Anal Methods, 2014; 6(10):3254-60.

Messina M, Nagata C, Wu AH. Estimated asian adult soy protein and isoflavone intakes. Nutr Cancer, 2006; 55(1):1-12.

Messina M. Soy and health update: evaluation of the clinical and epidemiologic literature. Nutrients, 2016; 8(12):754.

Messina MJ. Legumes and soybeans: overview of their nutritional profiles and health effects. Am J Clin Nutr, 1999; 70:439-50.

Miladinović J, Đorđević V, Balešević-Tubić S, Petrović K, Ćeran M, Cvejić J, Bursać M, Miladinović D. Increase of isoflavones in the aglycone form in soybeans by targeted crossings of cultivated breeding material. Sci Rep, 2019; 9(1):1-7.

Miller JM, Miller JC. Statistics and chemometrics for analytical chemistry. Technometrics. 6th edition, Pearson Education Limited, Harlow, UK, 2010

Momen SB, Siadat SD, Akbari N, Ranjbar B, Khajeh K Applying central composite design and response surface methodology to optimize growth and biomass production of haemophilus influenzae type b. Jundishapur J Microbiol, 2016; 9(6):1-6.

Morito K, Aomori T, Hirose T, Kinjo J, Hasegawa J, Ogawa S, Inoue S, Muramatsu M, Masamune Y. Interaction of phytoestrogens with estrogen receptors alpha and beta (II). Biol Pharm Bull, 2002; 25(1):4852

Myers RH, Montgomery DC, Anderson-Cook CM. Response surface methodology: process and product optimization using designed experiments. 4th edition, John Wiley Sons, Ltd., Hoboken, NJ, 2016.

Ogruc Ildiz G, Celik O, Atak C, Yilmaz A, Kabuk HN, Kaygisiz E, Ayan A, Meric S, Fausto R. Raman spectroscopic and chemometric investigation of lipid-protein Ratio rontents of soybean mutants. Appl Spectrosc, 2020; 74(1):34-41. 
Pakalapati G, Li L, Gretz N, Koch E, Wink M. Influence of red clover (Trifolium pratense) isoflavones on gene and protein expression profiles in liver of ovariectomized rats. Phytomedicine, 2009; 16:845-55.

Pompeu DR, Larondelle Y, Rogez H, Abbas O, Pierna JAF, Baeten V. Characterization and discrimination of phenolic compounds using fourier transform Raman spectroscopy and chemometric tools. Biotechnol Agron Soc Environ, 2018; 22(1):13-28.

Prabaningdyah NK, Riyanto S, Rohman A, Siregar C. Application of HPLC and response surface methodology for simultaneous determination of curcumin and desmethoxy curcumin in Curcuma syrup formulation. J Appl Pharm Sci, 2017; 7(12):058-64.

Putri AR, Rohman A, Riyanto S, Setyaningsih W. Authentication of patin fish oil (Pangasius micronemus) using FTIR spectroscopy combined with chemometrics. Indones J Chemom Pharm Anal, 2021; 1(1):23-8.

Riswanto FDO, Rohman A, Pramono S, Martono S. Application of response surface methodology as mathematical and statistical tools in natural product research. J Appl Pharm Sci, 2019; 9(10):125-33.

Riswanto FDO, Rohman A, Pramono S, Martono S. Employing an $\mathrm{R}$ software package rsm for optimizing of genistein, daidzein, and glycitein separation and its application for soy milk analysis by HPLC method. Indones J Chem, 2020; 20(5):1184-98.

Rohman A, Man YBC, Riyanto S. Authentication analysis of red fruit (pandanus conoideus lam) oil using FTIR spectroscopy in combination with chemometrics. Phytochem Anal, 2011; 22(5):462-7.

Rohman A, Putri AR. The chemometrics techniques in combination with instrumental analytical methods applied in Halal authentication analysis. Indones J Chem, 2019; 19(1):262-72.

Rostagno MA, Palma M, Barroso CG. Ultrasound-assisted extraction of isoflavones from soy beverages blended with fruit juices. Anal Chim Acta, 2007; 597(2):265-72.

Rostagno MA, Palma M, Barroso CG. Ultrasound-assisted extraction of soy isoflavones. J Chromatogr A, 2003; 1012(2):119-28.

Shafiee G, Saidijam M, Tavilani H, Ghasemkhani N, Khodadadi I. Genistein induces apoptosis and inhibits proliferation of HT29 colon cancer cells. Int J Mol Cell Med, 2016; 5(3):178-91.

Shen S, Wang J, Zhuo Q, Chen X, Liu T, Zhang SQ. Quantitative and discriminative evaluation of contents of phenolic and flavonoid and antioxidant competence for chinese honeys from different botanical origins. Molecules, 2018; 23(5):1-20.

Shiau AK, Barstad D, Loria PM, Cheng L, Kushner PJ, Agard DA, Greene GL. The structural basis of estrogen receptor/coactivator recognition and the antagonism of this interaction by tamoxifen. Cell, 1998; 95:927-937.

Siregar C, Prabaningdyah NK, Choiri S, Riyanto S, Rohman A. Optimization of HPLC using central composite design for determination of curcumin and demethoxycurcumin in tablet dosage form. Dhaka Univ J Pharm Sci, 2017; 16(2):137-45.

Sivoňová MK, Kaplán P, Tatarková Z, Lichardusová L, Dušenka $\mathrm{R}$, Jurečeková J. Androgen receptor and soy isoflavones in prostate cancer (Review). Mol Clin Oncol, 2018; 10(2):191-204.

Snyder LR, Kirkland JJ, Dolan JW. Introduction to modern liquid chromatography [Internet]. In Steinike SM Introd. to Mod. Liq. Chromatogr. 3rd edition, John Wiley \& Sons, Inc., Hoboken, NJ, 2010

Soto-Zarazúa MG, Rodrigues F, Pimentel FB, Bah MM, Oliveira MBPP. The isoflavone content of two new alfalfa-derived products for instant beverage preparation. Food Funct, 2016; 7:364-71.

Srivastava A, Singh V, Haque S, Pandey S, Mishra M, Jawed A, Shukla PK, Singh PK, Tripathi CKM. Response surface methodologygenetic algorithm based medium optimization, purification, and characterization of cholesterol oxidase from streptomyces rimosus. Sci Rep, 2018; 8(10913):1-13.

Sugiyama Y, Masumori N, Fukuta F, Yoneta A, Hida T, Yamashita T, Minatoya M, Nagata Y, Mori M, Tsuji H, Akaza H, Tsukamoto
T. Influence of isoflavone intake and equol-producing intestinal flora on prostate cancer risk. Asian Pacific J Cancer Prev, 2013; 14(1):1-4.

Suhandy D, Yulia M. Classification of Ground Roasted Kalosi and Toraja Specialty Coffees using UV-Visible Spectroscopy and PLS-DA Method. J Ilmu Pertan Indones, 2019; 24(1):73-81.

Talluri VP, Lanka SS, Saladi VR. Statistical optimization of process parameters by Central Composite Design ( CCD ) for an enhanced production of L-asparaginase by Myroides gitamensis BSH-3 , a novel species. Avicenna J Med Biotechnol, 2019; 11(7):59-66.

Valsecchi AE, Franchi S, Panerai AE, Rossi A, Sacerdote $\mathrm{P}$, Colleoni $\mathrm{M}$. The soy isoflavone genistein reverses oxidative and inflammatory state, neuropathic pain, neurotrophic and vasculature deficits in diabetes mouse model. Eur J Pharmacol, 2011; 650(2-3):694-702.

Wang FQ, Yao K, Wei DZ. From soybean phytosterols to steroid hormones. In: El-Shemy H (ed.). Soybean and Health. Intech Open, Rijeka, Croatia, pp 231-52, 2011.

Wang Y, Man Gho W, Chan FI, Chen S, Leung LK. The red clover (Trifolium pratense) isoflavone biochanin A inhibits aromatase activity and expression. Br J Nutr, 2008; 99:303-310.

Wehrens R. Chemometrics with R: Multivariate Data Analysis in the Natural Sciences and Life Sciences. Berlin: Springer, 2011.

Wijngaard $\mathrm{HH}$, Brunton N. The optimisation of solid-liquid extraction of antioxidants from apple pomace by response surface methodology. J Food Eng, 2010; 96(1):134-40.

Xiong W, Chen X, Lv G, Hu D, Zhao J, Li S. Optimization of microwave-assisted extraction of bioactive alkaloids from lotus plumule using response surface methodology. J Pharm Anal, 2016; 6(2016):382-8.

Yatsu FKJ, Koester LS, Bassani VL. Isoflavone-aglycone fraction from glycine max: a promising raw material for isoflavone-based pharmaceutical or nutraceutical products. Rev Bras Farmacogn, 2016; 26(2):259-67.

Yoshiara LY, Madeira TB, De Camargo AC, Shahidi F, Ida EI. Multistep optimization of $\beta$-glucosidase extraction from germinated soybeans (Glycine $\max$ L. Merril) and recovery of isoflavone aglycones. Foods, 2018; 7(7):110

Yoshiara LY, Madeira TB, Delaroza F, Da Silva JB, Ida EI Optimization of soy isoflavone extraction with different solvents using the simplex-centroid mixture design. Int J Food Sci Nutr, 2012; 63(8):978-86.

Yu Y, Jing X, Li H, Zhao X, Wang D. Soy isoflavone consumption and colorectal cancer risk: a systematic review and meta-analysis. Sci Rep, 2016; 6(25939):1-9.

Yuliani SH, Aji PDT, Sandrapitaloka AS, Restiana FR, Gani MR, Riswanto FDO. Effects of particle size, extraction time, and solvent selection on daidzein extracted amount from tempeh-a fermented product of soybean. J Pharm Sci Community, 2019; 16(1):44-9.

Yuliani SH, Gani MR, Istyastono EP, Riswanto FDO. Optimization of genistein and daidzein extraction from a tempeh- fermented product of soybean. J Pharm Pharmacogn Res, 2018; 6(4):231-41.

Yuliani SH, Istyastono EP, Riswanto FDO. The cytotoxic activity on T47D breast cancer cell of genistein-standardized ethanolic extract of tempeh - a fermented product of soybean (Glycine max). Orient J Chem, 2016; 32(3):1619-24

Zaheer K, Humayoun Akhtar M. An updated review of dietary isoflavones: nutrition, processing, bioavailability and impacts on human health. Crit Rev Food Sci Nutr, 2017; 57(6):1280-93.

Zeng H, Chen Q, Zhao B. Genistein ameliorates $\beta$-amyloid peptide (25-35)-induced hippocampal neuronal apoptosis. Free Radic Biol Med, 2004; 36:180-8.

Zhang HY, Cui J, Zhang Y, Wang ZL, Chong T, Wang ZM. Isoflavones and prostate cancer: a review of some critical issues. Chin Med J (Engl), 2016; 129(3):341-7.

Zhao-Min Z, Ho SC, Chen Y ming, Ho S, To K, Tomlinson B, Woo J. Whole soy, but not purified daidzein, had a favorable effect on 
improvement of cardiovascular risks: a 6-month randomized, double-blind, and placebo-controlled trial in equol-producing postmenopausal women. Mol Nutr Food Res, 2014; 58:709-17.

Zhuang XL, Fu YC, Xu JJ, Kong XX, Chen ZG, Luo LL. Effects of genistein on ovarian follicular development and ovarian life span in rats. Fitoterapia, 2010; 81(8):998-1102.

Ziaei S, Halaby R. Dietary isoflavones and breast cancer risk. Medicines, 2017; 4(18):1-11.
How to cite this article:

Riswanto FDO, Rohman A, Pramono S, Martono S. Soybean (Glycine max L.) isoflavones: Chemical composition and its chemometrics-assisted extraction and authentication. J Appl Pharm Sci, 2021; 11(01):012-020. 